\title{
THE FEMINIST ORIENTATION IN EDITH NESBIT'S GOTHIC SHORT FICTION
}

\begin{abstract}
For a long time critically neglected or disparaged, Edith Nesbit's Gothic fiction is beginning to receive the scholarly attention it deserves. This essay extends analysis beyond the much-anthologised "Man-Size in Marble" to argue that a feminist orientation is in evidence more widely in her works of supernatural short fiction. A preoccupation with gender is discernible in several stories that offer distinct gender critiques, and in further tales through imagery of the dead female body and the female revenant, as well as through the recurrent character motifs of the female Cassandra and the male Frankenstein. The essay also argues that the anti-vivisectionism of several stories is an aspect of this feminist orientation. The article recognises Nesbit as being a problematic figure for scholarly attempts to reclaim feminist authors, since she herself evinced ambivalence about the women's movement and the New Woman, but argues that the unleashing of Nesbit's most counter-hegemonic impulses in her Gothic writings points to the political significance of this generic form, making Nesbit a figure of substantial interest for scholars working on women's supernatural fiction.
\end{abstract}

\section{Keywords}

Edith Nesbit; gender; ghost story; abjection; science; vivisection.

\section{Word count}

8,514 (including references but excluding abstract and keywords) 
In recent years Edith Nesbit's work as a writer of Gothic fiction has begun to receive the attention it deserves. For a long time considered solely as an author for children, Nesbit's achievements in adult literary forms including poetry and novels had received scant critical attention, with her body of supernatural fiction being particularly overlooked. ${ }^{1}$ Recently, however, her much-anthologised Gothic short story "Man-Size in Marble" (1893) has been the subject of scholarly discussions by Nick Freeman and by Terry W. Thompson. ${ }^{2}$ Both writers analyse this in terms of the implied gender critique of this tale in which a complacent young husband's dismissal of his wife's forebodings leads directly to disaster. Indeed, Freeman presents the story as an instance of "New Woman Gothic", an example, that is, of how politically radical women at the fin de siècle were able to adopt Gothic conventions elsewhere employed to misogynistic effect, to interrogate patriarchal culture as powerfully as did the practitioners of realist New Woman fiction. ${ }^{3}$

Yet nowhere in Freeman's excellent account does he address a difficulty about reading Nesbit as a New Woman writer; namely, that while she lived a lifestyle that many would associate with this figure - rejecting much of the Victorian ideological construct of femininity and embracing political, intellectual and sexual freedoms - she expressly distanced herself from the political affiliations and demands of many New Woman writers. Nesbit refused attempts by her fellow Fabian Society activists to engage her in the Women's Movement. She declined to support the campaign for women's suffrage; satirised suffragettes in some of her children's fiction; and once horrified feminist members of the Fabian Society with a lecture on "The Natural Disabilities of Women". 4 Her opposition to aspects of first-wave feminist politics seems to have sprung from several sources, including scepticism about the value of inclusion in a corrupt political system and a belief that women having the vote might hinder the socialist cause, as well as a romantic longing for an intimacy between men and women which, she feared, the aggressive assertion of female rights placed in jeopardy. ${ }^{5}$ Freeman's sidelining of Nesbit's often explicit anti-feminist stance perhaps reflects an understandable desire to shift discussion away from biography and to focus on the text itself, and his careful reading of "Man-Size in Marble" justifies his claims for it as gender critique. And yet, the highly equivocal character of Nesbit's engagement with feminism surely raises further questions. Just how far might a feminist reading of Nesbit proceed when one considers other instances of her Gothic fiction? And if a feminist orientation is indeed discernible in this part of her literary output, then what might that suggest about the possibilities of this generic form over others? 
A scholar who has addressed the issue of Nesbit's anti-feminism is Amelia A. Rutledge, who characterises Nesbit as evincing an ambivalence towards feminism, with her "contrary impulses between sustaining and undermining the hegemony of conventional female roles" playing themselves out in her writing in a series of strategies through which feminist impulses emerge but are ultimately distanced, displaced, and curtailed. ${ }^{6}$ Her novels for adults, claims Rutledge, employed heroines apparently modelled upon the New Woman, but in a period when such characters had ceased really to be shocking, and in plots which contained their heroine's independence by concluding their stories with marriage. Rutledge suggests that her children's magical fiction allowed Nesbit greater scope for subversion - the marvellous releasing her from the demands of mimesis and lifting its associated repressions - but that even here this potential was constrained, with readers being able to dismiss transgressive representations as part of the charming but ultimately absurd delights of the carnivalesque. ${ }^{7}$ I suggest that given this albeit equivocal - endorsement of fantasy as a mode capable of liberating protest, it is surprising that Rutledge's only consideration of Nesbit's production of fantasy for adults occurs in a footnote in which she is described as having "also produced a small number of competent gothic short stories ... although only a few, most notably "Man-Size in Marble," effectively exploit gender issues."

In contrast to this judgement, the aim of the present article is to challenge both the marginal status accorded to Nesbit's Gothic fiction, and to argue for the Gothic or supernatural story as a form which lends itself to the liberation of some of her most counter-hegemonic impulses. The tendency of Nesbit critics to ignore or even disparage these of her fictions (Margaret Drabble deemed them "potboilers" produced from solely financial motives) reflects what Clare Stewart has identified as a more general tendency to dismiss Victorian writers' ghost stories as being "less important than other facets of [their] work". ${ }^{9}$ As Stewart contends, such judgements fail to reckon with the way in which the very "acceptability of a traditional form of entertainment" was exploited by female writers seeking to bypass the censorship of male editors and critics and include - if not necessarily explicitly feminist messages - covert subversive meanings which point to women's exclusion from the social realm. ${ }^{10}$ Even Julia Briggs, author of an extremely rich biography of Nesbit, seems to have concurred with many of the negative assessments of her ghost fiction. ${ }^{11}$ This is particularly curious given that both here, and in her early, seminal, study of the ghost story genre, Briggs too notes that marginal forms (such as ghost fiction and children's literature) gave writers a freedom symbolically to explore feelings too seditious or amorphous to achieve expression directly. ${ }^{12}$ 
I shall argue that this is indeed the case with Nesbit, whose elegantly crafted supernatural tales are populated with imagery and character-types which foreground women's marginal status and its deleterious consequences and hold up the patriarchal conventions of her society for scrutiny. Nesbit seems also to have made use of the brevity demanded of ghost stories by magazine publishers at the turn of the century, as well as the growing tolerance - even appetite - for explicit treatments of violence and sex, to disturb her readers without ultimately reassuring them. ${ }^{13}$ Kate Flint has suggested that "Unlike earlier Gothic fiction, and unlike the sensation fiction of the mid-century, Victorian ghost stories carry no guarantee that normalcy will be re-established in the fictional world through their conclusion: they often shock through the unresolved suddenness of their endings." ${ }^{14}$ This description is, I suggest, particularly apt in the case of Nesbit, whose endings are frequently brutal, tragic and bleak, and refuse the happy endings that generic conventions compelled in her work in other genres. If, for Rutledge, Nesbit's use of the marriage plot to bring about textual closure curtailed the subversiveness of her novels for adults, then it is significant that the form of the short supernatural story allows Nesbit not merely to eschew the marriage plot, but - as we shall see - to rip out the heart of it and dance on its grave.

\section{I}

Nesbit published four major collections of supernatural tales (many of which had been published previously in magazines). Grim Tales and Something Wrong appeared in 1893; Tales Told in the Twilight in 1897; and Fear in 1910. She continued to write and publish occasional horror stories until her death. Most of the stories were collected and reprinted in 2006 as The Power of Darkness: Tales of Terror, edited by David Stuart Davies (an expansion upon two previous collections using 'Tales of Terror' in their titles, and issued in 1983 and 1989). ${ }^{15}$

Of the motifs and concerns that recur across these tales, two clusters of themes stand out in particular. One is the theme of doomed or thwarted love. The stories frequently involve a triangular (or sometimes, rectangular) relationship of love rivalry. Often there is a narrator-protagonist who has lost out in this competition, typically to a friend, and who must now sublimate envy and sexual desire in the interests of maintaining a friendship with the couple. ${ }^{16}$ Other stories give prominence to the theme of disappointment in love by featuring couples whose relationship is revealed to be flawed or inadequate. Davies has argued that "Man-Size in Marble" (as well as "John Charrington's Wedding" and several other tales) "features the destruction of a strong 
loving relationship between a man and a woman. ${ }^{, 17}$ I would argue, however, that such tales actually work to reveal hidden flaws in heterosexual relationships that are only apparently strong (although they may be loving). In "Man-Size in Marble", the reader understands what the narrator-protagonist perceives too late, and then perhaps only partially: that his affection for his wife, though sincere, goes hand-in-hand with an attitude by which he condescends to her, infantilises her, and systematically dismisses her perceptions and judgements in favour of his own. In "Hurst of Hurstcote", a devoted husband mesmerises his wife and commands her soul not to leave its body until he too has died, an act of masculine control that nearly condemns her to a form of living death. ${ }^{18}$ Here and in other examples, the supernatural functions as a revealer of the fatal flaws hidden within a state of apparent married bliss, and the tales convulse with the misery of being failed by, or failing, the person one loves. There is, of course, nothing inherently feminist about the theme of disappointed love, and indeed this preoccupation is surely partially determined by Nesbit's own complicated romantic involvements. ${ }^{19}$ But as a trope within her fiction it has the function of allowing her to turn a sceptical eye upon the institutions of marriage and romance, and to analyse their failings in ways that indict the patriarchal systems within which they operate.

The second major cluster of themes concerns fear of death and horror at corpses. Nesbit's revenants are rarely the disembodied phantoms of other ghost stories. Instead they are often very much corporeal, and it is their materiality that horrifies quite as much as the fact of their return. Several of her stories feature the (apparently) reanimated dead, or exploit the repulsion felt by protagonists confronted by an out-of-place corpse. Indeed, so strong is this theme that it suggests connections with the notion of 'abjection' theorised by Julia Kristeva. In Kristeva's account of psychical development, 'abjection' refers to the act of separation by which, what will become an "I", first detaches itself from a primal flux of experience in order to produce itself as subject over and against a world of objects. All things are abject which recall to us that which we eject in order to be, and which thus remind us of the fragility of our being and the distinctions upon which we found meaning (self/other, inside/outside, human/animal, etc). A particular kind of abject, however, is constituted by all that recalls us to our materiality. Bodily excretions such as blood, faeces, puss, evoke the waste matter that we continually push aside in order to live, and that we ourselves will one day become. For Kristeva, the "utmost in abjection" is the corpse: the waste that has not been ejected but that has ejected me. ${ }^{20}$ The cadaver reveals to me the corpse that I am always on the brink of becoming. It "show[s] me" the death (my death) that I continually repress in order to live. ${ }^{21}$ 
Nesbit's stories seem to me to exploit a sense of abjection in two kinds of way. Firstly, they emphasise the thingness of human bodies as that which it might be better not to contemplate. That Nesbit was herself highly susceptible to the power of corpses to occasion a traumatic revelation of mortality is suggested by biographical material. In a note to George Bernard Shaw following the death of her friend, Philip Bourke Marston, she wrote: "I went and saw him today - but I was sorry afterwards [...] It was not Philip, but a vacant thing that had always underlain him, and which, apart from him, was ghastly". ${ }^{22}$ In many of her Gothic stories this sense of the abject physicality of the human self communicates with the theme of love: the idea of a love that is strong enough to bring back the dead appearing as a source both of hope (for the return of a beloved) and of horror (at the ghastly, vacant, thing they are, and have been revealed always to have been). It conditions too the frequent motifs of premature burial and human vivisection, in which it is precisely the dreadful materiality of the self that enables its conflation with dead matter or with animal flesh. ${ }^{23}$ Nesbit appears as a writer who was acutely aware of a realm of experience of the abject which, while normally repressed, might be evoked within fiction for the eliciting of horror.

Secondly, however, it is significant that it is very often women who appear in Nesbit's Gothic fiction in the place of the abject. I shall seek to demonstrate in my close readings of her stories that Nesbit draws attention to the ways in which certain forms of female subjectivity are excluded by her society. Kristeva's account is perhaps particularly illuminating here, as it emphasises that what is abject threatens not only the integrity of the subject but the entire social order from which his identity is derived (the abject "disturbs identity, system, order"; it reveals the "fragility of the law"). ${ }^{24}$ In constituting such a threat, however, the abject not only sickens and repulses but also "beseeches" and "fascinates", since it promises an annihilation of the self that is simultaneously a return to a oneness associated with a violent and ecstatic jouissance. ${ }^{25}$ In several of Nesbit's stories, male protagonists are attracted by transgressive females who promise a union that implies the loss or radical transformation of the masculine self. In each case, the male saves himself / is saved from this fate by an ejection of the feminine figure. Kristeva herself theorises the feminine as abject, since in her account, the maternal body becomes abject when the infant separates itself from the mother in order to enter culture. ${ }^{26}$ Yet much earlier than Kristeva and subsequent theorists of the monstrous-feminine, we find operating already in Nesbit's fiction, an awareness of how certain forms of femininity are rendered abject by a patriarchal society that requires their repression to reproduce itself. ${ }^{27}$ 
Both the themes of doomed love and horror at (female) corpses are central to the story I will now analyse. "From the Dead" (1893), like "Man-Size in Marble", makes use of a first-person male narrator who is doomed to regret at leisure his treatment of the woman he loved, and whose narration encourages the reader to find in his actions a significance that he himself does not wholly perceive. The story begins with something like the triangular, or rectangular, structure outlined above. Arthur Marsh ends his engagement after reading a letter from his fiancé to another man whom she loves. The letter has been passed to him by Ida Helmont, sister of Arthur's rival, and even in the bitterness of his disappointment and betrayal, Arthur perceives that Ida secretly loves him. A year passes and the two marry, with Arthur reporting that he is more in love than ever. Three weeks into their marriage, however, Ida makes a confession: the letter was a forgery, written by herself. Arthur reacts with fury and tells Ida he can no longer love her and that they must part. Within hours, however, he has repented, and returns from a soul-searching walk longing to embrace her and to give, or beg, forgiveness. But she has gone, and Arthur spends the following months searching for her in vain.

The scene of Ida's revelation is resonant with implied commentary on the social roles expected of both men and women. Arthur (who is narrating the story some five years later) makes clear that to a great extent his performance of outraged morality was a sham. His fury was, he states, motivated not by "anger at the lie" but by "wounded vanity" (36) at his deception. As he describes his emotions, the first-person pronoun appears four times in italics: "That $I$ should have been tricked, that $I$ should have been deceived, that $I$ should have been led on to make a fool of myself [...]" (36). And even in the heat of his stinging pride, he knows that "I did not mean what I said. No, oh no, no; I did not mean a word of it. While I was saying it, I was longing for her to weep and fall at my feet, that I might raise her and hold her in my arms again" (36). The strong implication of this scene is that while both Ida and Arthur desire intimacy above all else, this is fatally disrupted by his masculine investment in abstractions and in certain gender scripts. Arthur reports having felt that "it was rather creditable in me to be so angry", and having had a "foolish sense of there being something rather noble in my indignation" (36); and that "my ideal of her was shattered, at least I felt I ought to think that it was shattered" (37) [my italics]. He expects the conventional behaviour of the Victorian angel, desiring her to adopt an attitude of fawning humility and supplication. Ida, however, refuses the role of feminine subservience, neither weeping nor prostrating herself, but instead attempting to explain, and when she is prevented from so doing, 
scrutinising him and demanding to know if he is in earnest. For the third time Arthur shrugs off her touch. He is doing - his later self insists - the exact opposite of what he longs to do, which is to love and to forgive. And Nesbit hints heavily that this is more than individual perverseness, but a matter of a man performing in obedience to the social codes by which male-female relationships are culturally regulated.

That what is at issue is a critique of gender norms and relations is made still more clear when Arthur finally hears from Ida, and learning that she is dying, rushes to her, only to be upbraided by the older woman who has nursed Ida and come to love her. Arthur is too late: Ida has died through complications in childbirth (compounded, it is implied, by heartbreak), and her nurse bitterly accuses him of betraying the woman who loved him. We learn that Ida had assumed something of the angelic behaviour that she had previously rejected, allowing her nurse and others to think her a fallen woman, pregnant outside of wedlock, rather than to taint her husband with the dishonour of having (as she thinks) abandoned her. The nurse's lament, "Oh, to think as God A'mighty's made men able to measure out such-like pecks o' trouble for us womenfolk!", generalises the cruelty which she judges to have killed Ida as being characteristic of men's relationship to women, and while her complaints against Arthur are clearly not all justified (she accuses him of never having loved Ida) the challenge to male behaviours remains a powerful one.

Arthur is plunged into an agony of remorse, but his failure of his wife is still yet to reach its completion. Lying awake at night, he hears sounds coming from the room in which her corpse is laid out. Although initially struck with morbid fear, eventually he finds himself wishing that, dead or alive, she would come back to him and give him her forgiveness. As if in answer, the sound arises of footsteps outside and "uncertain hands" (43) at the latch of his door, before it opens, and "the figure of my dead wife came in" (43). As Davies notes, Nesbit pulls no punches here. ${ }^{28}$ The abjectness of the animated corpse is fully emphasised, with the pronoun "it" employed three times in quick succession as the uncanny figure appears at the foot of the bed. But the bitterest twist is still to come. As the corpse looks at Arthur with "love unspeakable", it reveals the forged letter to have been truthful in spirit (Arthur's fiancé was really in love with the other man). As the "thin, monotonous voice" (43) continues, begging for love and for forgiveness, Arthur manages to stammer out confirmation of his love. But when the corpse murmurs "I suppose [...] you would be afraid, now I am dead, if I came round to you and kissed you?" (44), Arthur shrieks in terror and winds himself in his bed sheets. Perhaps the most devastating sentence in the tale is the simple "There was a moment's 
silence" (44), in which the reader is left to imagine the full impact of Ida's second, and final, rejection. Ida's corpse is discovered in a "huddled heap" (44) outside the bedroom. While a doctor suggests that death had been misdiagnosed, Ida having been merely in a state of catalepsy, Arthur knows only that whether Ida were dead or alive, "if I had had room in my coward's heart for anything but the unreasoning terror that killed love in that hour, I should not now be here alone" (44). The story's remorselessly bleak denouement skilfully exploits the ambivalence of the scene, eliciting readerly pity for, and horror of, the human/inhuman figure of Ida's corpse. It also carries through the scepticism about romantic love that has been in evidence from the start. Arthur's confident declaration to his new wife that "Nothing in heaven or earth can come between us now" (35) has been exposed as delusion. He has twice failed the woman he loves; once, through masculine vanity and pride, and then again, even after receiving the second chance for which he had longed, through a horror of death that the tale pessimistically suggests may be a stronger force in human nature than is love. In each instance, Arthur mortifies his desire for the impossible figure that Ida presents, and in rejecting (abjecting) her, he "give[s] birth to [him]self", re-securing his position in the masculine symbolic, albeit at the cost of the union he craves. ${ }^{29}$

"From the Dead" numbers among several of Nesbit's tales in which men fail women, in which a prominent place is given to the female corpse, and in which the marriage plot leads, almost inexorably, to the burial plot. Diana Wallace has suggested that the ghost story is "perhaps the most dream-like form of the short story", extending Clare Hanson's argument that short stories are structured like dreams, since they prioritise elements that express unconscious forces over rational cause and effect sequence. ${ }^{30}$ Developing this further, I suggest that it is important to attend to the visual elements of Nesbit's short stories, which, as in a dream, sometimes seem to be translating ideas that cannot be expressed in words. In this respect it is highly significant that so many of her tales proffer tableaux of the dead female body, and of the married couple lying dead in the grave. ${ }^{31}$ This constitutes a visual language expressive of a profound negativity about the place of women in society, and the character of the institution that is supposed by many to be a woman's best chance of happiness and fulfilment. Such images can also be read as symbolic of women's exclusion from the social realm, and this is particularly so in those stories that feature dead women attempting in vain to return to the world of the living. "Uncle Abraham's Romance" and "The Ebony Frame" are further examples of the plot structure in which male protagonists are prevented / saved from yoking themselves to a transgressive female figure, by her abjection from the material, social, world (these tales 
emphasise the man's regret at his 'deliverance' more strongly still). In the latter, a revenant who had been burnt as a witch describes her expulsion from a patriarchal culture in these terms: "You know I was more learned than women of that day. [...] Just because I had looked at the stars and had gained more knowledge than they, they must needs bind me to a stake and let me be eaten by the fire" (148). I contend that such an attention to the visual motifs of the stories is further warranted by the emphasis in some of them upon emotional realities that cannot be articulated in words, and "From the Dead" is exemplary in this respect. We have seen that the revenant Ida looks at Arthur with "love unspeakable" (43). And Arthur's narration twice insists "there are some things that cannot be written" $(38,42)$. The story's final words concern the child of Arthur and Ida, four years old at the time of narration, and symptomatic of a trauma that cannot be worked through: "it has never spoken and never smiled" (44).

\section{III}

In the much-later "The Pavilion" (1915), the theme of women's social marginality is given quite explicit treatment, although it is distanced from the present day by the story's setting in the past. A third-person narrator introduces us to four young people who are enjoying a "long leisurely visit" (86) at the ancestral home of one of their number during the 1860s. From the first, the structuring dynamic of sexual desire and rivalry is in evidence. Frederick Doricourt, the owner of the estate, is in love with Ernestine, but so too is his friend Eugene Thesiger. In turn, Ernestine's friend, Amelia Davenant, loves Thesiger, but since Amelia is a young woman whom nobody notices, this is something of which the others are unaware. Nesbit contrasts the two women and dissects the bases of their very different degrees of social visibility. Ernestine is described as possessing a kind of ersatz glamour: a "prettyish" girl, she achieves the "illusion of beauty" through her airs and her ability to make the most of her modest physical charms (85). She is also pretentious and stupid, providing the story with some rather heavy-handed comedy as she unwittingly betrays her ignorance in a series of conversational solecisms. Amelia, on the other hand, is "very nearly plain" (86). The narrator reports that she "was one of those featureless blondes who seem born to be overlooked" (86), and that she "often asked uninteresting questions" (90). It soon becomes apparent, however, that these observations are offered ironically by a narrator who is commenting on the unjust neglect of Amelia by a social milieu dazzled by the counterfeit charms of Ernestine. In fact, Amelia's questions are very much to the point, as are her observations and growing forebodings. In contrasting the two young women, Nesbit is highlighting the social privilege accorded to 
female beauty (as well as the artifice that often lies behind this) and the concomitant neglect of women who do not possess this social capital.

The action centres upon a bet made between the two young men as to which of them will sleep at night in a pavilion rumoured to be haunted. Family legend holds that all those who have slept there have been found dead the following morning. Thesiger is to stay in the pavilion from one to three in the morning, and Frederick from three to five. While Ernestine regards this as a delightful caper and encourages the men, Amelia is immediately possessed of a sense of foreboding - although it is left ambiguous as to whether this is an intuition of supernatural menace or merely the danger presented by the men's rivalry. In fact, Amelia here appears as one of several Cassandra figures in Nesbit's fiction, who foresee disaster but are disbelieved by the men who would be capable of preventing it, and which provide Nesbit a way of commenting on the social marginality of women. ${ }^{32}$ In the case of Amelia, the story establishes that not only does she lack power as a woman, but also that, lacking physical beauty, she is without one of the few means by which women might influence men. Amelia herself understands this, at one point urging Ernestine to ask the men to call off the bet, saying "They'd mind, if you asked them" (92).

Amelia is prevented from acting herself by the social proprieties of the time. Repeatedly, her desire to intervene is checked by other characters' insistence upon the prescribed behaviour for young ladies. She proposes going down herself to tell the young men not to go to the pavilion, but Ernestine responds with a shocked "You couldn't. I shouldn't let you dream of doing something so unladylike. What would the gentlemen think of you?" and "Forward and fast, auntie would call it" (93). Nesbit's narrator presents himself/herself in this tale as something like the reader's guide into a world of by-gone customs and mores. In several narratorial interventions, the 1860s are contrasted with the present as a time of charming naivety, but also as being in thrall to repressive notions of sexual and moral propriety. At times, these asides seem to invite Nesbit's twentieth-century readers to pride themselves on their progress beyond such unenlightened times, as when the narrator comments on the gentlemen leaving the ladies to smoke: "Those were the days of consideration for the ladies who had not yet learned that a cigarette is not exclusively a male accessory like a beard or a bass voice" (89). Ernestine's objections ("unladylike", "fast and forward") euphemistically recall Amelia to the implied sexual impropriety of her being alone at night with young men, and this reminder is forceful enough to forestall the intervention that might have warded off disaster. 
Amelia instead waits by her dressing room window and watches, but when morning dawns and Thesiger has not emerged, "without another thought for the ladylike and the really suitable" (95) she goes down to Frederick and urges him to accompany her to the pavilion. No longer retiring and passive, she casts off his attempts to mollify her, insisting "I hate you [...] and I am going to see what has happened. Come or not, as you like' (95). The two go to the pavilion, where Amelia discovers Thesiger's apparently lifeless body, the creepers of the pavilion having penetrated the building and round themselves around his neck, leaving "little white wounds, like bloodless lips half open" (98). Throughout the emergency is it Amelia who acts decisively, bringing a dagger for protection and sending Frederick to the house for brandy and a doctor, while he behaves with condescension and dull conventionality, saying she will regret her "emotion" (97) when Thesiger is found only to have fainted, and hesitating "with thoughtful propriety" (96) to leave her alone with the prostrate body. But it is anyway too late: Thesiger has been killed by the vampiric vines that he alone had known about and that he had intended would make his rival their victim, his broken watch having prevented him from leaving in time to have Frederick take his place.

Typically of the bleakness of Nesbit's Gothic tales, Amelia's transformation from dull wallflower to intelligent and determined actor has been to no avail. One of the final images is provided by Frederick's perspective when he returns to the pavilion with help, and sees that "On the bench lay a dead man and kneeling by him a living woman on whose warm breast his cold and heavy head lay pillowed" (97). The image presents a terrible mockery of the romantic scene that Amelia might have dreamed of: in it, she cradles in her arms a lover who she knows to have loved another, and knowing him too "for the murderer he was" (99). Further confirmation that suffering and ignominy are to be Amelia's only rewards for her creditable conduct are provided by the last paragraph, in which the narrator tells us that she died "only the other day", her epitaph (delivered by Ernestine) attributing her lifelong spinsterhood to "an indiscretion when she was young [...] it was the sort of thing that stamps a girl, you know" (99).

The narrative emphasis on a difference between then and now produces an ambiguity around the gender critique proffered in this tale. Some of this critique is directed towards mid-Victorian social proprieties that no longer apply in the second decade of the twentieth century, and to that extent, Nesbit's readers may have been able safely to distance from themselves the satiric power of the story. It might appear, then, that the feminist impulses here are indeed being displaced, as Rutledge argues is characteristically the case in Nesbit's adult fiction. But at a still deeper level "The 
Pavilion" pulsates with anger at a culture that values women primarily as adornments, circumscribes their fields of action, and discounts women of intelligence and acuity; and this message remains relevant for Nesbit's contemporary audience, as perhaps it does for readers of her fiction today.

\section{IV}

In this final section I wish to suggest that Nesbit's anti-vivisectionism is an aspect of her feminist orientation. In the early twentieth-century she wrote three Gothic stories in which vivisectionists turn their practise upon human subjects. Vivisection had, in this period, become deeply entwined with gender politics, with women featuring in powerful positions in an anti-vivisection movement that had many convergences with the women's movement, and that frequently presented opposition to vivisection as an aspect of women's special mission. ${ }^{33}$ As Carol Lansbury argues, it seems that vivisection had become a powerful symbol for a cluster of gender and class-related concerns, including women's vulnerability to marital violence and to a masculine medical profession that pathologised them - and that animals had come (perhaps unconsciously) to be seen as "surrogates for women who read their own misery into the vivisector's victims". ${ }^{34}$ As a political radical, Nesbit would have been familiar with the imagery and rhetoric of the movement, and among her friends, acquaintances, and the thinkers and artists whom she admired, numbered several high-profile anti-vivisectionists (George Bernard Shaw, Ouida, Robert Browning, Christina Rosetti, John Ruskin). In her own fictional treatments of vivisection she draws upon the Frankenstein motif of the vainglorious man who becomes blinded to morality and to the difference between knowledge and wisdom. ${ }^{35}$

"The Five Senses" (1909) makes central to its narrative the gendered terms within which opposition to vivisection was at the time framed. The story is told by an anonymous narrator who presents himself as an emissary from, and the reader's guide to, the sphere of professional science, although we learn that "another hand" (presumably one of the story's principals) has provided "much of the detail", and is "responsible for an emotionalism which is, I believe, wholly foreign to my own style" (153). The narrator regrets that his first account, which "dealt fully, as I am, I may say without immodesty, qualified to do, with all the scientific points of the narrative", has had removed from it most of these scientific details; an omission which the narrator believes "appears to me to destroy most of its interest" (153). This somewhat pompous preamble establishes that the narrator misunderstands the interest of the narrative he is relating, conjuring an implied author and reader for whom it is something other than the scientific issues that are of 
consequence; namely, the emotional, and perhaps the ethical ones. It also establishes a dichotomy between science and the emotions that the story will continue to exploit, and that is recognisable from earlier anti-vivisection fictions such as Wilkie Collins' Heart and Science (1883). What is subsequently related to us is the story of a Professor Arthur Boyd Thompson, a rising star of the medical sciences who falls in love with his cousin, Lucilla. They become engaged, but when she learns of his experiments on live animals, Lucilla calls it off, and Boyd Thompson learns that "Lucilla never could, never would love or marry a vivisectionist" (154).

In acting thus, Lucilla is doing just as the anti-vivisectionists of the period urged. As Lansbury has shown, campaigners subscribed to a Hogarthian narrative (drawn from his prints The Four Stages of Cruelty, 1751) according to which cruelty brutalised the perpetrator, and the tormenter of animals would progress on to human beings. ${ }^{36}$ Antivivisection propaganda of the period urged young girls never to marry a vivisectionist, since social sanctions against the perpetrators were deemed an important instrument of persuasion, and for fear that his wife would become the first human victim of the vivisector's awakened passion for torture. ${ }^{37}$ The nascent scientist of the "The Five Senses" is introduced to us as a boy pulling the wings off flies in a futile attempt to find out how they fly. When he later chooses the profession of medicine, Nesbit presents this as a "cloak" "under [which] the growing fever of scientific curiosity could be sated on bodies other than the cloak-wearer's" (154). Boyd Thompson enters medicine not in order to alleviate suffering but to pursue a thirst for scientific knowledge that the word fever suggests amounts to an unhealthy passion. In a later encounter between Boyd Thompson and Lucilla, the former presents the case for vivisection in terms of the advances in medical science that the practise can bring, and the alleviation of human suffering thus enabled. But Lucilla, who as a child had cried at the dead flies destroyed by her cousin, insists "it's wrong if it's done in that way" and that dogs and human beings are alike "God's creatures" (156). There is an interesting ambiguity about this scene to the extent that neither antagonist is presented as being entirely in the right: Lucilla is mistaken in her assertion that Boyd Thompson does not love her, and an emphasis on her bourgeois parental home, which speaks "eloquently of the sheltered life" (156), appears to suggest the partial grounding of her opposition to vivisection in naivety and conventionalism; while Boyd Thompson in his turn listens with well-meaning condescension, pitying and smiling inwardly at her objections. But it is ultimately Lucilla's asseveration - "I know I'm right [and] You'll know I am, some day" (157) - that the narrative will come to endorse. 
The main action takes place years later, with Boyd Thompson now a Professor who has discovered a drug capable of intensifying sensation in animals, and which he intends to extend to humans. A key passage strongly suggests that the story's critique of (a certain kind of) scientific ambition is simultaneously a critique of gender. Nesbit utilises an imagery - conventional in its day and particularly associated with the archvivisector Claude Bernard - of Nature as a woman, her modesty violated by the male scientist: "He had found out one of the secrets with which Nature has crammed her dark hiding-places" (158). ${ }^{38}$ She also presents Boyd Thompson's motivations in terms that emphasise male competitiveness and glory-seeking, and in so doing suggests his earlier idealistic defence of vivisection to have been less than entirely ingenuous: "Ferrier, and Leo, and Horsley; those he would outshine. Galileo, Newton, Harvey; he would rank with these" (158). But when the professor's thoughts turn to finding "a human rabbit" (158), remembrance of the woman he loves leads him to determine that none other than himself shall be his experimental subject. Applying the drug to one sense at a time, Boyd Thompson achieves a superhuman heightening of sensory experience. But when he applies the drug to all of his senses at once, he finds that far from delivering the hoped-for "position of supreme power over men and things, transforming him from a Professor into a demigod" (161), the drug has instead the effect of heightening his senses "a thousandfold", while "paralys[ing] every muscle" (163). Now "powerless as a cat under kurali" (163) - experiencing intensified sensation while utterly helpless and immobile the vivisector has been placed in the very position of the animals upon which he experiments.

Pronounced dead following a cursory examination of his apparently lifeless body, Boyd Thompson is interred in the family charnel house, where he resolves to face death bravely. But when Lucilla arrives to weep over his body and bid him farewell he finally comes to understand fear of death. Though he has now recovered the ability to move his eyelids, and so has within his grasp the chance of salvation, he fears to place her sanity in jeopardy: "'She believes me dead. If I open my eyes it will be like a dead man looking at her [...] People have gone mad for less. Lie still, lie still'” (165). But when an involuntary movement does occur, Lucilla does not react as supposed. She tells him she thinks he may be able to hear her, and urges him to speak; and though when he utters her name she "scream[s] aloud pitifully, and leap[s] for the entrance" (166), she returns moments later to reassure him, before fetching a doctor. Whether she has had to overcome her own moment of terror and abjection is unclear. But her capable response to this emergency implicitly mocks medical myths about female mental fragility, and contrasts with at least 
two other stories from Nesbit's oeuvre in which men faced with the animation of the apparently inanimate do indeed respond with morbid terror or with madness. ${ }^{39}$ Reversing the gender positions, as well as the outcome, of "From the Dead", this tale gives us a female character in whom love is strong enough to triumph over fear of death. The coda of the story tells us that Boyd Thompson and Lucilla marry, the professor having renounced vivisection as well as the "dreadful researches which tend to merge the chemist and biologist in the alchemist and the magician" (167). Far from following the Hogarthian narrative familiar from much anti-vivisection literature of the time, the story resembles much more the revision of this narrative that Lansbury claims was typical of fictions written by female, and especially feminist, authors, in which a woman romantically attached to a vivisector is able to reform him. ${ }^{40}$ In "The Five Senses", the Frankenstein representative of male scientific ambition is saved (both physically and morally) by a woman from whom he learns emotional and ethical knowledge. The tale is one of few in Nesbit's oeuvre in which the marriage plot brings with it a happy ending.

V

From the perspective of the twenty-first century, Nesbit's position on feminism may seem paradoxical. Acutely aware of the oppressive nature of patriarchal relations, and seeking to escape the burden of these in her own life, she nonetheless evinced what appear as some surprisingly anti-feminist opinions. This has led Rutledge to describe her as representing a "middle term between equally adamant feminists and anti-feminists". ${ }^{41}$ And yet, Ann Heilmann and Valerie Sanders have contended that Victorian feminism and anti-feminism were in fact rarely "stable positions," but were often "embraced by one and the same writer simultaneously or successively in different textual outlets." ${ }^{, 42}$ Perhaps Nesbit's ambivalence, then, rather than simply establishing her as an in-between figure, expresses something of the contradictions and conflicts that women across the spectrum of feminist/anti-feminist positions were attempting to negotiate.

The "textual outlet" of her Gothic fiction, however, sees Nesbit give voice much more frequently to one current within this ambivalence than the other. The genre's licence to shock, and its iconography of death and abjection, seem to have provided her with a vocabulary for the expression of her most counter-hegemonic impulses in relation to gender. In her imagery of women in death-like states, of female revenants refused admittance to the world, and in her use of the Cassandra figure, there emerges with painful clarity a sense of her frustration at a social order that privileges an idealised, commodified and artificial version of femininity, while excluding alternative forms of 
female subjectivity. Although Nesbit feared that aggressive feminists were endangering the possibilities for loving unions between the sexes, interestingly, in her Gothic fictions, it is much more frequently male desires which place such intimacy in jeopardy, men's need for recognition within a patriarchal order leading them to reject or degrade the relationships with women that they crave.

Far from being the derivative and perfunctory efforts described by her critics, Nesbit's Gothic tales proffer powerful visions of female exclusion, but also, sometimes, of transgressive female agency. Her horror fiction deserves re-evaluation both by Nesbit scholars, and by those interested in the significance of the supernatural story as a form that gave women writers of the long nineteenth century a vehicle for questioning the material and social conditions of their existence.

\section{Acknowledgement}

I'd like to thank Dr Bryony Randall from the University of Glasgow, with whom I first encountered Nesbit's supernatural fiction during our work on a co-authored project on women's Gothic. I have found invaluable in the shaping of my ideas both our discussions then, and her comments on a previous draft of this paper.

\section{Notes}

\footnotetext{
${ }^{1}$ An exception to this is a 1998 essay by Lowell T. Frye, "The Ghost Story and the Subjection of Women: The Example of Amelia Edwards, M. E. Braddon, and E. Nesbit," Victorians Institute Journal 26 (1998): 167-209. This article does not seem to be widely known among recent Nesbit scholars (and I have only recently discovered it) but it provides a thoughtful discussion of "Man-Size in Marble" and "John Charrington's Wedding", and several of Frye's observations about Nesbit's exposure of the destructive powers of gender and marriage conventions coincide with my own.

${ }^{2}$ Nick Freeman, “E. Nesbit's New Woman Gothic,” Women's Writing 15.3 (2008): 454-69. Terry W. Thompson, "Presentiments of Evil': Sourcing Frankenstein in Edith Nesbit's 'Man-Size in Marble'," The CEA Critic 73.2 (2011): 91-100. Thompson's article discusses Nesbit's tale as consciously drawing upon Mary Shelley's Frankenstein in its presentation of a young woman who becomes victim of her husband's self-absorption, and although he is not explicit in deeming the text a feminist one his reading brings out the story's pronounced elements of gender critique. See also Kathleen A. Miller, who contrasts "Man-Size in Marble" with two other Nesbit stories which, she argues, point to the possibility of more equal relationships between men and women: "The Mysteries of the In-Between: Re-reading Disability in E. Nesbit's Late Victorian Gothic Fiction," Journal of Literary and Cultural Disability Studies 6.2 (2012): 143-157.

${ }^{3}$ Freeman 454-5.

${ }^{4}$ See Julia Briggs, Edith Nesbit: A Woman of Passion (Chalford: Tempus, 2007 [1987]).

${ }^{5}$ See Briggs 16-17, 84-5, 138-9, 356-7.

${ }^{6}$ Amelia A. Rutledge, "E. Nesbit and the Woman Question," Victorian Women Writers and the Woman Question, ed. Nicola Diane Thompson (Cambridge: Cambridge University, 1999) 223.

${ }^{7}$ Briggs also suggests the subversive potential in Nesbit's children's books of magic and the supernatural, which allowed her to explore "the meaning and implications of hidden wishes and desires." Edith Nesbit 421.

${ }^{8}$ Rutledge 236. In fact Rutledge gives greater consideration to Nesbit's Gothic output in her entry "E. Nesbit (15 August 1858 - 4 May 1924)," Dictionary of Literary Biography: British Fantasy and
} 
Science-Fiction Writers before World War I, ed. Darren Harris-Fain, vol. 178 (Washington, DC: Bruccoli, 1997) 200-13. Here too, however, her evaluation is rather lukewarm, with "Man-Size in Marble" and "The Shadow" being praised, while many other stories are deemed not noteworthy, "conventional", or as "lacking intensity" (205).

${ }^{9}$ Clare Stewart, “Weird Fascination': The Response to Victorian Women's Ghost Stories,” Feminist Readings of Victorian Popular Texts, ed. Emma Liggins and Daniel D. Duffy (Aldershot: Ashgate, 2001). Drabble is quoted by Thompson, 99. Doris Langley Moor, Nesbit's first biographer, deemed her ghost stories "singularly ineffectual and now deservedly forgotten" - quoted in David Stuart Davies, "Introduction," The Power of Darkness: Tales of Terror, by Edith Nesbit (Ware: Wordsworth, 2006) 12.

${ }^{10}$ Stewart 112.

${ }^{11}$ Briggs devotes just a page of her biography to substantial discussion of Nesbit's horror stories, focusing upon "Man-Size in Marble", and judging Something Wrong to be "rather a poor collection" in comparison to Grim Tales (187). Here and in scattered other allusions to her supernatural fiction, her interest lies predominantly in how the tales reflected Nesbit's superstitious nature, and her childhood terrors and phobias.

${ }^{12}$ Briggs, Edith Nesbit 419 and 421. Julia Briggs, Night Visitors: The Rise and Fall of the English Ghost Story (London: Faber, 1977) 15, 23. This contains no reference to Nesbit's ghost fiction.

${ }^{13}$ See Freeman 463.

${ }^{14}$ Kate Flint, "Sensation," The Cambridge History of Victorian Literature, ed. Kate Flint (Cambridge: Cambridge University, 2012) 235.

${ }^{15}$ Edith Nesbit, The Power of Darkness: Tales of Terror, ed. David Stuart Davies (Ware, Wordsworth: 2006) 36. All the stories I discuss are taken from this edition, and quotations will be given parenthetically in the body of the essay.

${ }^{16}$ Examples include "John Charrington's Wedding", "Hurst of Hurstcote", and "The Shadow"; the last of which is significant as unusually here it is a woman who provides the narrator-protagonist disappointed in love. The structure of male rivalry over a woman is also central to "The Pavillion" (to be discussed) and "The Power of Darkness".

${ }^{17}$ Davies 10.

${ }^{18}$ See Victoria Margree and Bryony Randall, "Fin-de-siècle Gothic," The Victorian Gothic: An Edinburgh Companion, eds. Andrew Smith and William Hughes (Edinburgh: Edinburgh University, 2012) 225-7.

${ }^{19}$ A similar triangular structure involving desire, disappointment and rivalry, presumably obtained in Nesbit's own marriage. When her unmarried friend Alice Hoatson became pregnant, Nesbit and her husband Hubert took Alice into their home and presented her child as their own. Only later did Nesbit discover that the child was indeed Hubert's, who went on to father another baby with Alice while the three raised the family together. See Briggs, Edith Nesbit.

${ }^{20}$ Julia Kristeva, Powers of Horror: An Essay on Abjection, trans. Leon S. Roudiez (New York:

Columbia University, 1982) 3-4.

${ }^{21}$ Kristeva 3.

${ }^{22}$ In Briggs, Edith Nesbit, 145.

${ }^{23}$ Kristeva writes: 'The abject confronts us [...] with those fragile states where man strays on the territories of animal.' 12 .

${ }^{24}$ Kristeva 4.

${ }^{25}$ Kristeva 1.

${ }^{26}$ Kristeva 13.

${ }^{27}$ See for example, Barbara Creed, "Horror and the Monstrous-Feminine: An Imaginary Abjection", Screen 27.1 (1986): 44-71.

${ }^{28}$ Davies 11.

${ }^{29}$ Kristeva 3.

${ }^{30}$ Diana Wallace, "Uncanny Stories: The Ghost Story as Female Gothic," Gothic Studies 6.1 (2004): 57-68 (58-9).

${ }^{31}$ A focus on the spectacle presented by the female body in death, or in death-like states, occurs in "Man-Size in Marble", "From the Dead", "Hurst of Hurstcote", "John Charrington's Wedding", "The Mystery of the Semi-Detached", "The Shadow", and "The House of Silence". "John Charrington's Wedding" and "Hurst of Hurstcote" both close with a final image of a married couple lying dead together in their grave.

32 Other examples are to be found in "Hurst of Hurstcote" and "Man-Size in Marble". Of the latter, Freeman identifies the superstitious housekeeper Mrs Dorman as a Cassandra figure, but as Thompson 
makes clear, the young wife Laura herself experiences "presentiments of evil" (23) which are cavalierly ignored by her husband.

${ }^{33}$ French suggests the anti-vivisection societies leaderships were between $40 \%$ to $60 \%$ female. Richard D. French, Antivivisection and Medical Science in Victorian Society (Princeton: Princeton University, 1975) 239.

${ }^{34}$ Coral Lansbury, The Old Brown Dog: Women, Workers, and Vivisection in Edwardian England (Madison: University of Wisconsin, 1985) 128.

${ }^{35}$ Nesbit's use of the Frankenstein motif in her Gothic fiction is also noted by Rutledge, and Davies, as well as by Thompson.

${ }^{36}$ Lansbury 132.

${ }^{37}$ Jessica Straley, "Love and Vivisection: Wilkie Collins's Experiment in 'Heart and Science,"” Nineteenth-Century Literature 65.3 (2010): 348-73 (359).

${ }^{38}$ Bernard "described nature as a woman who must be forced to unveil herself when she is attacked by the experimenter, who must be put to the question and subdued". Lansbury 163.

${ }^{39}$ The other example is "The Power of Darkness", in which a young man schemes to send his love rival mad, but falls victim to his own trap.

${ }^{40}$ Lansbury $144-5$.

${ }^{41}$ Rutledge 236.

${ }^{42}$ Ann Heilmann and Valerie Sanders, "The Rebel, the Lady and the 'Anti': Femininity, Antifeminism, and the Victorian Woman Writer," Women's Studies International Forum 29 (2006): 289300 (298). 